\title{
Barriers and facilitators to local food market development: A contingency perspective
}

\author{
Sherrie K. Godette, ${ }^{a} *$ Kathi Beratan, ${ }^{\mathrm{b}}$ and Branda Nowell c
}

North Carolina State University

Submitted August 16, 2014 / Revised November 25, 2014, and February 3 and April 10, 2015 /

Accepted April 14, 2015 / Published online June 16, 2015

Citation: Godette, S. K., Beratan, K., \& Nowell, B. (2015). Barriers and facilitators to local food

market development: A contingency perspective. Journal of Agriculture, Food Systems, and Community

Development, 5(3), 79-96. http://dx.doi.org/10.5304/jafscd.2015.053.012

Copyright (C) 2015 by New Leaf Associates, Inc.

\begin{abstract}
Many government and community supported programs and initiatives have been developed recently in response to social, economic, political, and environmental conditions presumed to be caused by the globalized food system. These programs are focused on building local food economies as a means to rectify these conditions and to enhance local communities. While efforts to strengthen local food systems (LFS) are increasing in number, little is known about how

a* Corresponding author: Sherrie Godette, Department of Public Administration, North Carolina State University; 212 Caldwell Hall, Campus Box 8102; Raleigh, North Carolina 27695 USA; s.k.godette@gmail.com

${ }^{b}$ Department of Forestry and Environmental Resources, North Carolina State University.

c Department of Public Administration, North Carolina State University.

\section{Note}

Funding for this project was provided by the USDA National Institute of Food and Agriculture (NIFA) through the Agriculture and Food Research Initiative (AFRI) Foundational Program (Award Number 2011-67023-30061).
\end{abstract}

well these initiatives are working and what factors contribute to or limit program impact. In this paper, we report on a comparative assessment of barriers and facilitators to the development of local food markets conducted from the perspective of 11 local food coordinators in the eastern region of North Carolina. Interviews with Cooperative Extension agents were analyzed based upon the contingency perspective to assess whether the development and success of local food markets depend on local conditions. Our findings suggest that local food markets are more or less successful given certain local conditions, but that local food markets are not being developed based upon assessment and analysis of local context. Further, institutional factors (e.g., food safety policy and institutional buyer attitudes) were found to have even more impact on local food market development than local conditions (e.g., urban proximity). The information presented in this report is intended to inform policymakers, planners, and administrators regarding environmental factors that should be considered when making decisions and plans to increase viability of LFS development. 


\section{Keywords}

local food systems; local food markets; local food system development; local market development; contingency; local food policy; GAP certification

\section{Introduction}

In recent years, U.S. government agencies and nonprofit assistance organizations have responded to the profoundly negative ecological, sociocultural, and economic consequences associated with the dominant food system by creating programs to develop, promote, and support local food economies (Ilbery, Watts, Simpson, Gileg, \& Little, 2006; Friedmann \& McNair, 2008; Mirosa \& Lawson; 2010). For example, the U.S. Department of Agriculture (USDA) began its Know Your Farmer, Know Your Food initiative in 2012 to implement the president's plan to strengthen local and regional food markets (Maples, Morgan, Interis, \& Harri, 2013; USDA, 2012). Such programs reflect a belief that the "localization trend shifts focus back to the context specific ecological and social factors global markets tend to externalize (O'Hara \& Stagl, 2001, p. 535). Many of these programs are developed at some local level, proliferate due to policy initiatives mandated at the federal level, and are "operationalized," evaluated, and then expanded by a range of actors at state, regional, and community levels. A typical example is the USDA's Farm to School Program, a federal policy that encourages public schools to increase the amount of locally produced food purchased and consumed. The development of the necessary administrative, financial, and transport infrastructure for this program is left to local institutions. The 10\% Campaign in North Carolina is a state-level program response to this nationally established local food policy (Center for Environmental Farming Systems [CEFS], n.d.; Dunning, Creamer, Lalekacs, O'Sullivan, Thraves, \& Wymore, 2012).

While efforts to strengthen local food systems are increasing in number, little is known about how well these initiatives are working and what factors contribute to or limit program impact. Assessments of new initiatives can enhance knowledge about the

${ }^{1}$ By environmental or contextual conditions we mean geographic, socioeconomic, and institutional features dynamics of food system change and increase the likelihood of program success (McKenzie-Mohr \& Smith, 1999). Given the proliferation of new programs and initiatives and the complexity of local food systems, it is particularly important to understand how different markets interact with different environments and contexts so that program developers can select interventions that are well suited to their particular settings and conditions.

The local food system literature lacks accounts and assessments of the local food movement from the perspectives of local agents tasked to facilitate local food development. This paper begins to address this knowledge gap by investigating the facilitators and barriers to local food market development through the experiences and perceptions of Cooperative Extension agents designated as local food coordinators in an eleven-county region in eastern North Carolina. This is a state and region that has actively been promoting local food system development. The North Carolina Cooperative Extension Service has been an active participant in and change agent for local food development in the state; "local foods" was designated as a flagship program of this agency in 2010. Engaging in local food market development activity represents a significant proportion of extension agents' current tasks. The primary research questions we address are:

1. What local food markets are present, actively promoted, and developed across counties?

2. Is the existence of local food markets associated with urban proximity?

3. What other local conditions drive and limit the prevalence and success of different local food markets?

The information in this report is intended to provide policy makers, planners, and administrators with greater insight into how local environmental factors ${ }^{1}$ can impact the development of local food systems. We argue that local food

characteristic of an area. 
systems are complex systems, and given their complexity, local conditions should be considered and emphasized when making decisions and plans toward engineering these systems. The results of this study also suggest the types of support local agents need in order to implement more effectively state-level policy associated with local food system development.

\section{Local Food Systems Definitions and Typology}

A local food system(LFS) can be defined as a system in which foods are grown or produced, processed, and distributed locally at the household, neighborhood, municipal, and even regional level (Dahlberg, 1994). While there is no universally accepted definition of "local food," there are characteristics used to define such systems, including geographic proximity, production methods, and absence of intermediated steps such as aggregation and processing (Martinez et al., 2010). One of the most important defining characteristics is that information about the particular farm of origin and production methods for each specific food item is available to the end consumer, and is considered to add value to the product. Development of a LFS involves the organizing, planning, and implementation of new programs and markets intended to support local farmers and lessen the distance between producers and consumers. This interest in developing and strengthening linkages between local producers and consumers has been reflected in recent scholarship on mid-scale value chains that focuses on increasing market access for small- and mid-scale farmers (Stevenson, Clancy, King, Lev, Ostrom, \& Smith, 2011).

Local food systems include both indirect and direct market arrangements. Direct markets are outlets where farmers sell their fresh-picked produce and value-added products directly to consumers (Andreatta \& Wickliffe, 2002; ). Direct marketing activities include farmers' markets, roadside stands, community supported agriculture (CSAs), and pick-your-own operations. We define farmers' markets as any temporary or permanent outlet, whether a building or land space, that facilitates direct food transactions between farmers and consumers. CSAs are marketing arrangements in which members purchase shares of a farmer's expected yield before planting, and receive products at regular intervals during the growing season (Martinez et al., 2010). Other direct markets such as roadside stands and U-pick operations are arrangements in which consumers travel to farm sites to purchase and/or pick their own produce. Indirect markets are supply chains in which intermediaries such as brokers, distributors, grower cooperatives, food hubs, and food service operations facilitate exchanges between farmers and end consumers. These intermediated markets can be considered local if the information about the source of each product is retained and they have only a very limited number of intermediaries, such as when a farmer sells directly to a retailer or restaurant (Low \& Vogel, 2011; Martinez et al., 2010).

\section{Contingency Perspective of Local Food System Development}

Previous studies addressing the opportunities for and challenges to LFS development have reported various environmental or contextual conditions that influence its progression (Andreatta \& Wickliffe, 2002; Maples et al., 2013; Martinez et al., 2010; Mirosa \& Lawson, 2010; Smith \& Miller, 2011). For example, Martinez and his colleagues found that capacity constraints for small- and midsize farms include lack of distribution systems for moving local food into mainstream markets such as institutional and conventional markets; limited research, education, and training for marketing local food; and uncertainty related to regulations that may affect local food production, such as food safety requirements (Martinez et al., 2010). Local food systems have also been found to be influenced by characteristics of area residents, such as age, sex, income level, ethnicity, food preferences, food ideology (i.e., organic versus conventional production methods), and the degree of selfsufficiency vs. civic engagement (Maples et al., 2013).

A commonly reported environmental condition viewed as impacting local food development is proximity to population-dense (urban) areas (Low \& Vogel, 2011; Martinez et al., 2010). A USDA Economic Research Service study of LFSs reported that most farms selling directly to consumers are 
small farms with less than US\$50,000 in total farm sales, and are located in urban corridors of the Northeast and the West Coast (Low \& Vogel, 2011; Martinez et al., 2010). While these studies report correlations between local food market prevalence and geographic conditions, as well as other environmental conditions, to our knowledge no studies examine whether the barriers and challenges to the success of different local food market arrangements (e.g., farmers' markets, food stands, CSA cooperatives) vary based upon similar conditions of geographic location and population density.

Because of the reported links between contextual conditions and local food market development, we view the contingency perspective as a good lens through which to address the question of what environmental conditions drive and pose challenges to the development of local food systems. The contingency perspective looks at effectiveness as a function of the degree of congruence or "fit" between structural and environmental variables (Heiens \& Pleshko, 2011; Shenhar, 2001). This reflects the view of many organizational scholars since the 1970s, that there exists no set of universal strategies that is optimal for all organizations or systems (Galbraith, 1973; Ginsberg \& Venkatraman, 1985; Heiens \& Pleshko, 2011). For local food systems, the contingency perspective suggests that the economic performance of a given local food market is dependent on its level of congruence with relevant structural and environmental conditions such as population density, farm characteristics, and transportation infrastructure. In this study the contingency perspective is used as a tool for exploring the importance of considering contextual conditions when making planning, policy, and implementation decisions geared toward local food system development.

\section{Methods}

Data was drawn from a stratified sample of 11 counties in eastern North Carolina by a universitybased research team. The sample was stratified based upon county geographic designation (defined and discussed later). These counties were chosen because expanding local food production and consumption was identified as an important goal by regional level governmental institutions observed in the region. For this study, the authors represent 'outsiders' to the phenomenon of inquiry. While the authors have expertise in LFSs, community/ economic development, and institutional design, none of the authors have a direct affiliation with university or county extension.

North Carolina is an information-rich place in which to study LFS development at state, regional, and county levels. The state ranks seventh nationally in farm profits with a net farm income of over US $\$ 3.3$ billion. Agriculture contributes US $\$ 70$ billion annually to the state's economy, accounts for 18 percent of the state's income, and employs over 17 percent of the work force (NCDA\&CS, 2012).According to Local Harvest (2011), the state has an estimated 828 farmers' markets, 260 CSAs, and over 1,000 farm locations, including U-pick, roadside stands, and agritourism operations. In addition, Census of Agriculture (USDA, 2012) data shows that direct-to-consumer food sales in North Carolina have grown over 9 percent. Between the years of 2007 and 2012 direct consumer sales in the study region increased approximately 78 percent. The prevalence of local food markets and growth of direct market sales are indications that the interest in and action toward local food system development exists.

Several interest groups in North Carolina are dedicated to building sustainable local food systems; these include Appalachian Sustainable Agriculture Project (ASAP), Carolina Farm Stewardship Association (CFSA), Carteret Catch, Central Carolina Community College (CCCC), and the Center for Environmental Farming Systems (CEFS). A particularly influential initiative is the $10 \%$ Campaign, launched in July 2010 through a partnership between CEFS and the North Carolina Department of Agriculture and Consumer Services (NCDA\&CS). The goal of this program is to encourage North Carolinians to spend at least 10 percent of their food dollars on locally grown and/or produced food.

Actions by these state-level interest groups and institutions at multiple levels led to designation in 2010 of "local foods" as the flagship Cooperative Extension program in North Carolina (Dunning et al., 2012). To implement this new policy, each 
county's Extension director designated a member of their field faculty as that county's local foods coordinator. These agents were tasked with supporting the 10\% Campaign through promoting and facilitating local food market development. While many extension agents had previously been in engaged in local food activities prior to this formal designation, this initiative provided state-level support and legitimacy to the local food movement. The designation of Cooperative Extension as local food agents has been characterized as an effort towards developing institutional change in the state's food system (Dunning et al., 2012). Several county agents attended state-sponsored professional training programs, where they were informed of current methods and approaches to building community-based food systems (for more details about these trainings, see Dunning et al., 2012; and Mettam, King, \& Dunning,2013).

While LFS interest and development has grown in North Carolina and across the U.S., close observation of the process suggests that market development is not widespread and benefits generated from these markets are not distributed equally. For instance, local food research suggests that while the popularity of local food markets has grown, limited market accessibility is increasing disparities in nutritional opportunities for low-income consumers (Jones \& Bhatia, 2011) and in economic opportunities for small-scale limited resource farmers (Anderson, 2007; Beratan, Jackson, \& Godette, 2014; Stevenson et al., 2011). Therefore, more indepth examination of how local context can impede the development or expansion of local food markets is necessary, as it may give us insight into what conditions contribute most to the limited accessibility disadvantaged groups have.

\section{Study Data}

Data for this study consisted of secondary analysis of datasets that describe existing local food system conditions and infrastructure within each county, as well as in-depth key informant interviews with

\footnotetext{
2 The term "boundary-spanning individuals" refers to actors that are strongly linked internally and externally, so that they can both gather and transfer information from outside their sub-unit (Tushman, 1977; Tushman \& Scanlan, 1981). In this
}

county-level cooperative extension agents. Extension agents were chosen as knowledgeable informants for local food market activity within their counties. These boundary-spanning individuals ${ }^{2}$ engage with local producers and community members on a daily basis, and serve as a critical link between farmers and state-level policy and resources. Therefore, county extension agents can provide a unique and important perspective on factors that challenge and facilitate the success of different local food marketing strategies.

Telephone interviews lasted one hour to an hour and a half. Key informants were asked to identify and describe what local food markets were present or being developed in their county, and what factors they viewed as facilitating or limiting their development. The transcribed interviews were coded in three steps. First, the interviews were categorized as urban, peri-urban, or rural based on county proximity to population-dense areas. Within each category, agent statements were structured based on the types of local markets (direct vs. indirect). Third, statements were organized based on agent references to specific markets they identified as existing in their county, then coded based on factors identified as facilitating or impeding each local food market arrangement.

Secondary county-level data from the 2012 Census of Agriculture used in data analysis included geographic (population density), socioeconomic (median education and income), and agriculture data (farm population and size) (Table One). In addition, information about local food markets in each county was obtained from the Local Harvest National Directory.

The U.S. Office of Management and Budget classification of geographical statistical areasmetropolitan, micropolitan, and rural—was used to determine each county's geographic designation. The OMB defines metropolitan counties as territories (or counties) with a high degree of social and economic integration, with the core factor measured by commuting ties. Micropolitan statistical

study, extension agents are viewed as boundary spanners within multiple systems (e.g., government and food systems) attempting to create and strengthen ties between actors and the organizations necessary to develop LFSs. 
Table 1. County Geographic, Socioeconomic, and Farm Characteristics

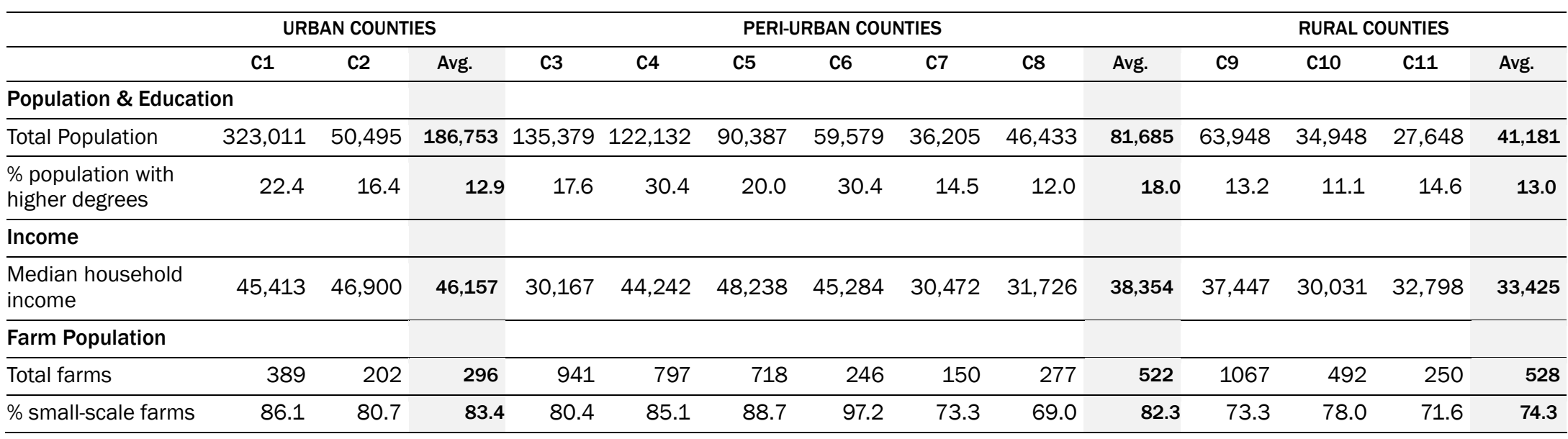

areas consist of a minimum of one urban cluster with a population of at least 10,000 but less than 50,000, along with adjacent territory having a high degree of social and economic integration with the core (OMB, 2012). While OMB does not explicitly define rural statistical areas, we define them as areas with relatively low population density and distant from areas with a high degree of social and economic integration. For the purpose of simplification, we refer these geographic designations as urban, peri-urban, and rural, respectively.

In qualitative research, the concept of transferability ${ }^{3}$ rather than generalizability is often used to evaluate the trustworthiness of analysis (Bloomberg \& Volpe, 2012; Guba \& Lincoln, 1998). Following this tradition, we emphasize that findings and conclusions in this study should be viewed as transferable insights. It is likely that findings in this setting might be useful in other settings, with similar contextual features.

${ }^{3}$ In qualitative research the concept of transferability does not involve general claims; rather it involves applying findings in similar contexts or settings

\section{Findings}

In this section we provide basic social and economic profiles of the different county population designations. In addition, we outline findings regarding extension agent identifications of existing markets and the factors they view as driving and facilitating their efforts in the development of different local food market arrangements.

\section{County Geographic and Socioeconomic Characteristics}

Two out of the eleven counties are classified as urban, six are periurban, and the remaining three are rural. In 2012, the average population in the urban counties was 186,753 , in the peri-urban counties 81,685 , and in the rural counties 41,181 (Table 1). The average median household incomes for the urban, peri-urban, and rural counties were US $\$ 46,157$, US $\$ 38,354$, and US $\$ 33,425$, respectively (USCB, 2011). Urban and peri-urban counties had the largest

(Bloomberg \& Volpe, 2012). 
Table 2. County Local Food Market Count

\begin{tabular}{|c|c|c|c|c|c|c|c|c|c|c|c|c|c|c|}
\hline & \multicolumn{3}{|c|}{ URBAN COUNTIES } & \multicolumn{7}{|c|}{ PERI-URBAN COUNTIES } & \multicolumn{4}{|c|}{ RURAL COUNTIES } \\
\hline & C1 & $\mathrm{C2}$ & Avg & $\mathrm{C3}$ & C4 & C5 & C6 & $\mathrm{C7}$ & $\mathrm{C8}$ & Avg & c9 & C10 & C11 & Avg \\
\hline \multicolumn{15}{|l|}{ Market Type } \\
\hline Farmers' Markets & 3 & 2 & 2.5 & 3 & 0 & 4 & 2 & 2 & 1 & 2.0 & 2 & 2 & 2 & 1.3 \\
\hline CSAs & 2 & 0 & 1.0 & 1 & 3 & 2 & 1 & 0 & 0 & 1.2 & 2 & 0 & 1 & 1.0 \\
\hline $\begin{array}{l}\text { Total Local Food } \\
\text { Markets }\end{array}$ & 5 & 2 & 3.5 & 4 & 3 & 6.0 & 3 & 2 & 1 & 3.2 & 2 & 2 & 3 & 2.3 \\
\hline
\end{tabular}

percentage of the population with higher degrees of educational attainment ${ }^{4}(19.4 \%$ and $18 \%)$ compared to rural counties (13\%) (USCB, 2011). A large percentage of the farms within the different counties are small-scale farms, ${ }^{5}$ with urban and peri-urban counties having a higher proportion of small-scale farms (between 82-83\%) than rural counties (74\%) (U.S. Census of Agriculture, 2012).

\section{Local Market Prevalence}

Although there is some variation in the prevalence of different local food markets by population density, a pattern is not strongly expressed in this sample (Table 2). Both urban counties in the sample had existing farmers' markets, and the county with the largest population had the greatest number of farmers' markets (3), while the second urban county had two. The county with the largest population density also had the most CSAs (2), while the other urban county had none.

The peri-urban counties averaged two farmers' markets per county, ranging between zero and four. The county with greatest number of farmers' markets had the third largest population among the eleven counties, while the county with the fewest had the second largest population. CSAs were present in all but two counties; the county with fewest farmers' markets had the largest number of CSAs. The county with fewest CSAs had the lowest population.

Among the rural counties, the county with the largest population had no farmers' markets while the other two counties had two each. The most populous of the rural counties had two CSAs, the

\footnotetext{
${ }^{4}$ Higher degrees of educational attainment refers to the percentage of adults in a county who are 25 or older who attained a degree higher than a high school diploma.
}

least populous had one, and the remaining county had none. It is important to note that while agents identified roadside stands as local food markets which exist in the counties, the lack of comprehensive data on these markets limited our ability to provide accurate prevalence data.

\section{Perceived Relationships Between Context and the Success of Local Food Markets}

Across the eleven counties, agent interviews suggested a potential disconnect between the strategies that are being promoted at the state level and how these strategies are implemented at the local level. From the extension agent perspective, there was an expectation for them to implement a specific set of local food system development strategies that may or may not be feasible given the conditions of their county. While there were no clear correlations between population and the number of local food markets, agents did view the success of different local food market arrangements to be dependent on certain other contextual factors. This was not apparent in agent identification of the market strategies they promote; agents tended to promote the same strategies in all of the counties. However, the agents did express concerns with the general application of a suite of local food strategies in all contexts. For example:

The biggest issue with local food initiatives is that they are coming up with the solutions without finding out what the problem is.... There is no one-size-fits-all local food system.... No one has bothered to research the

\footnotetext{
5 Small-scale farms are defined based upon the USDA-ERS farm typology definition. Refer to http://www.ers.usda.gov/ publications/eib-economic-information-bulletin/eib-110.aspx
} 
difference between counties before coming up with the solutions.... A round block cannot fit into a square hole.

One of the biggest issues is the preconceived ideas that because one program or set of activities works for one area or context doesn't mean it will in another.... We need to take a case by case basis.

Many agents identified proximity to densely populated areas, high income, and high educational attainment as necessary factors for the successful development of some local food markets such as CSAs and farmers' markets. They explained that the socioeconomic makeup and concentration of population are important factors that influence farmers' market decisions. In addition, they believe that these are important features to consider when decisions are made as to what local food markets should be developed.

\section{Drivers and Challenges of Direct Local Food Markets} The agents described local direct markets as the most favored types of markets in their counties, stating that farmers view them as more straightforward, accessible, and profitable. Direct markets in general were the most promoted local food market strategy. Agents described contextual factors that they view as important determinants of the success or viability of direct market strategies, and how these differ between farmers' markets, CSAs, and roadside stands.

\section{Farmers' Markets}

Many agents view farmers' markets as the most accessible kind of local food market. A few questioned the viability of this strategy, focusing on the need for a more concentrated population to support the market and on the challenge of reduced market share due to competing local food strategies:

Farmers' markets are no good for [our] county because the county does not have the concentrations of populations in certain areas.

We have tried several different times, in several different years to set up a farmers' market here in [city $\mathrm{X}]$ but it has not worked....The biggest problem is that there is no market here for that. The homeowners can go right to those roadside stands, which are fairly convenient around town.

Despite widespread endorsement of farmers' markets as an accessible strategy, all county agents interviewed expressed concern about the lack of participation by local farmers in farmers' markets. The reasons included lack of local demand, a history of farmers exporting to areas with larger populations, and competing alternative market outlets. In particular, agents from urban and periurban counties talked about farmer exportation of food and competing markets. For example, one agent from an urban county stated:

The [city X] farmers' market is comprised [sic] of several small farmers. Over the years there has been a somewhat increase in patronage... Most farmers take their products to farmers' markets in [bigger City A] or may have a couple of contracts with someone or sell on the farm.

Another substantial concern expressed by agents is that the establishment of farmers' markets is not driven by consumer demand. One rural agent, referring to a newly opened governmentsponsored farmers' market, stated:

[The county] just opened a farmers' market three weeks ago. It consists of only [Vendor A] and [Vendor B], which are permanent vendors. This building transition was made possible by grant money...opening day was comprised [sic] of politicians... after that day it only had marginal participation...if [Vendor A and B] did not exist the building would probably be abandoned.

In sum, agent remarks indicate that farmers' markets are most viable in more urban areas with sufficient population density to support the market. While they can also be a viable strategy in less urbanized areas, success is more contingent upon 
minimal competition from alternative local food market strategies and upon commitment of sustained participation from local farmers, in addition to consumer demand.

\section{Community Supported Agriculture (CSAs)}

The agents reported difficulties in promoting CSAs, and described them as a strategy that was most readily accepted by consumers with aboveaverage incomes. As one peri-urban agent put it, "CSAs have to have a certain structure in order to flourish where the income per capita is very high.... This is also true with organics." The agents explained that because CSAs necessitate greater investment from the consumer as well as sharing production risks by both consumer and producer, CSAs are more likely to succeed in areas having more individuals with relatively high disposable incomes.

Another challenge to the viability of CSAs is simply the fact that this market strategy is not well known in the region. Not only is the level of consumer demand uncertain, but farmers are less familiar with the operation of these markets. In addition, the transaction costs are higher. One agent who spearheaded formation of a CSA stated that although consumer demand was demonstrated, the farmers showed a significant level of resistance towards participation. The agent described this experience as:

Excessive hand-holding and teeth-pulling to get them to participate.... Even if I show farmers the evidence of new opportunities, they still will not expand to meet this new market that is being developed.

Collectively, the interviews suggest that CSAs may be best suited to higher-income areas. In addition, successful introduction of CSAs into new areas may require extensive institutional support to educate both farmers and consumers about the benefits of this market strategy.

\footnotetext{
${ }^{6}$ Note that this study was a part of larger study that was being conducted in the region at the time. Therefore, we engaged with several local food stakeholders within the region about
}

\section{Roadside Stands}

While a few agents described roadside stands as favored by some farmers in their county, none mentioned active promotion of these markets. Some of the factors that agents identified as contributing to the viability of roadside stands are tradition, convenience, and tourism:

Farmers sell [produce] almost exclusively through roadside stands due to the [geographic] layout and demographics of our county.

Due to the county tradition [a number of decades] and the roadside stand location on the route to the beach, people tend to visit the roadside stands.

The agents noted that roadside stand ventures tend to be owned by farmers with a considerable amount of land and extra produce to sell. Agents therefore associated these markets with mediumto larger-sized farms. As two peri-urban agents stated:

We have a few farmers that are producing small amounts of veggies that they sell at roadside stands during the summer. Usually the farmer has some property and owns a roadside stand where they can market their own product.

The county is comprised [sic] of small-scale farms who are operated by retired agriculture teachers.... The typical fruit and veggie farm is a hobby farm. We have three to four farmers that are larger scale.... These farmers tend to have roadside stands or sell at the market.

In all, based on our discussions with agents and other local food stakeholders in the region, ${ }^{6}$ roadside stands appear to be one of the simplest and more flexible marketing strategies. They require little to none of the coordination between

similar topics. We focused on Cooperative Extension agents in this study because they have an important and unique perspective on these topics. 
Table 3. Direct Markets: Development Barriers and Facilitators

\begin{tabular}{lll}
\hline Market Type & Facilitators & Barriers \\
\hline Farmers' markets & High population density & Lack of local demand \\
\hline CSAs & Local farmer and consumer commitment & Competing (local) food outlets \\
& $\begin{array}{l}\text { - Population with higher average household } \\
\text { incomes } \\
\text { - Institutional support to educate both farmers } \\
\text { and consumers }\end{array}$ & $\begin{array}{l}\text { Consumer and producer novelty and uncertainty of } \\
\text { strategy }\end{array}$ \\
\hline Roadside stands & \begin{tabular}{l} 
Tradition, convenience and tourism of area \\
\hline
\end{tabular} & Limited land and marketing capacity \\
\hline
\end{tabular}

producers required by farmers' markets. In addition, very little infrastructure is needed to support roadside stands. This is in contrast to farmers' markets, which generally require significant public space and infrastructure that may need to be assembled and disassembled each market day. The operation of roadside stands is much simpler than CSAs, which require more complicated management systems to support communication and distribution to consumers. To see a list of contextual factors that may drive or impede the development of direct local food markets, see Table 3.

\section{Barriers to Local Indirect Market \\ Development and Viability}

Local indirect market arrangements are less prevalent than direct markets throughout the area. All of the agents reported difficulty in facilitating indirect and institutional market exchanges and contracts. The majority of agents were able to recall only a few-if any-farmers in their county that sell or contract with indirect markets. The following factors were identified by the agents as systemic barriers to farmer entry into indirect markets.

Local indirect market is challenged by producer cost, uncertainty, and risk regarding labor and production. According to the agents, farmers are not convinced that there is any real incentive to sell to indirect markets due to the associated costs, uncertainty, and risk. Farmersespecially small-scale farmers-are not convinced that the likely return on investment is sufficient to take the risk of changing. One peri-urban agent described this issue in terms of farmers' uncertainty about benefits, labor and production costs:
Labor is an issue....If farmers were to ramp up to enter into more institutional-type sales, this would require an increase in production and farmers would be faced to revisit the labor situation. Because of this uncertainty and increase in cost, they are not sure they can get the income increases that would warrant such a transition...Therefore, this is not just a matter of creating demand but also a matter of helping farmers figure out how to minimize their costs to produce so that they can sustain their operations to meet demand.

Indirect market transactions are challenged by producer limited land and capital resource capacity. Accessing indirect markets was described as requiring significantly greater production output in order to meet institutional market demands relative to direct market strategies. Increased production translates into need for more land resources and the environmental conditions to support agricultural expansion. Consequently, in more urbanized counties, significant consideration is given to land value and how it influences production decisions. An urban and peri-urban agent conveyed these points:

Growers that sell to institutions will require more land and will have to be located in a county where the tax values in land are lower. As you get closer to [large] populations the price and tax value of land increases; therefore, farmers living in these areas have substantially higher overhead costs. Farmers simply cannot afford to sell produce to institutions or wholesalers if they are in close proximity to high populations.... They are barking up the 
wrong tree.... The rainfall in this county is insufficient and the land value is too high.

\section{Farmers' attitudes towards change are viewed as significant barriers to farmer access to} indirect markets. Many extension agents in this study identified farmers' resistant attitudes towards change as a significant factor impeding development and facilitation of indirect market exchange. As two peri-urban agents noted:

They [farmers] are driven by a mentality that is driven by its environment....Some farmers are in their 80s.... try to keep up with the trends in local food and try to inform the farmers; however, the responsiveness is low....They don't seem to be interested in change.

The automatic assumption is that farmers want to sell to institutions.... In our county they do not.

Agents also stated that farmers are aware that there are significant barriers to accessing indirect markets based on their own past experiences or through hearing of the experiences of others. Several agents shared stories of farmers' negative experiences in attempting to sell to local institutions such as public schools. According to one peri-urban agent, after going through stringent processes to meet the requirements set by the institutions, the farmers were "contracted" for only one delivery and no other sales were made. The agent recalling the story stated:

Three of our strawberry farmers collaborated to get GAP [Good Agricultural Practices] certified and only sold to the school once. The farmers got certified on a Monday, but could not sell to the school until that week....They sold to the school the next week, the following week was spring break, and the next week the grow season was over. The farmers went

\footnotetext{
${ }^{7}$ In this paper, the concept of institution is applied in two ways: (1) to describe the policies, behaviors, and norms of institutional buyers (e.g., institutional buyer attitudes and behaviors toward buying local); and (2) to describe an
}

through the extensive process of getting certified and did not recoup that cost.

According to the agents, farmers also believe that indirect markets cannot offer the same prices and practical benefits as direct markets. An urban agent stated:

The farmers' feeling is to not sell to institutions because they [institutions] are unable to pay the amount the farmer can get retail....These institutions have limited money. To sell to schools, farmers have to be big enough to sell to gain their contracts. These programs such as farm-to-school may make the school systems buy; however, it does not support price increases for the farmers' product....Also the school is not some place where farmers can dump their surplus.

Agents also mentioned the increased oversight and paperwork that is often associated with indirect markets as a factor limiting farmer interest in pursuing indirect markets. The farmer point of view is that institutional market initiatives represent excessive regulation, oversight, paperwork, and unrealistic standards as well. Referring to a local institutional food initiative, a rural agent stated, "The majority response from the farmers is that they are scared to death to get involved in any [institutional system] due to the extent of government regulation that come along with it."

The agents emphasized that the difficult challenge of convincing farmers to change is made even more difficult when there is not much incentive or evidence to justify change.

It is difficult for farmers to jump outside the box as well as for others to convince them to change. Even if you enforce the "see it to believe it" practice, they have to see it a lot.

Institutional barriers ${ }^{7}$ impede indirect market

actual organization or network (e.g., schools or hospitals). Here, institutional barriers refer to institutional buyer attitudes and behaviors about purchasing from local farmers. 
arrangements between county farmers and local institutional food buyers. The agents identified the prioritized values of institutional buyers as barriers to access to indirect markets by local farmers. For example, one peri-urban agent stated:

It's so hard getting [local] food in the school system and on military bases.... They say they want it, they want it, they want it, but then they put all these boundaries up and so it is not easy to get it [local food] in these places.

According to agents, the conventional decision-making processes of institutions and the valuation of food (i.e., the perceptual value of food) from institutional and consumer perspectives also impede indirect food exchange. One periurban agent conveyed this point by explaining why many institutions are not buying local food:

...because of this cheap food mentality....In other words, if you are going to sell either to the school or the military, the compelling thing is that the produce must be cheap, it must be the lowest cost....It is sort of a commodity view of veggies....It's a difference in the way people view their food.

Describing the influence of institutional decision making on smaller scale farms, another peri-urban agent stated:

For institutions like the school and military the purchasing decisions are all about the bottom line...getting the cheapest price. If we want to have local farms be the recipients of these contracts, this cannot be the basis of their decisions. There have to be other incentives for the military and schools to go to local producers. Only in rare cases will the local producer be able to make the changes necessary to meet such standards.

These findings suggest that local farmer access to institutional markets is severely limited by institutions-especially public institutions - inability or unwillingness to alter attitudes involving food valuation.
Food safety regulations limit small-scale producer access. All agents stated that government and institutional level policies related to food safety, such as the Good Agricultural Practice (GAP) and Good Handling Practices (GHP) certification processes, are difficult for small- and midsize farms to navigate:

There is only one required GAP certification; that is the USDA GAP certification. If you don't produce more than [US] $\$ 500,000$ of produce in a three-year period, you are not required to be GAP-certified. In this county, there is only one producer that produces enough to get GAP-certified. Most of the county producers do not produce enough to meet this requirement. So the only time they may be required of this is when a private retailer or wholesaler requires it by their own standard. Different retailers, distributors, or brokers have their own unique requirements or standards. This is what makes GAP certification difficult to understand because it is such a vague concept.

One peri-urban agent described the effect of these policies on small farmers:

The current state of the local food system, in a sense, is killing the small farmer.... The push is to go back to the small farmers and to local foods; however, the problem is that regulations such as the Food Safety Act and the GAP certification do not support the local food mentality.

More rural agents than agents from other population designations reported having GAPcertified farmers in their counties. According to agents, this is due only to institutional push to conform to these standards. One rural agent stated, "The current farmers who are GAP certified are so because they had no other choice but to get GAP certified, it is necessary in order to sell the product."

\section{Insufficient regional infrastructure creates barriers to entry to indirect markets.}


Overwhelmingly, agents identified lack of local regional distribution and processing infrastructure as a major barrier impeding expansion of local institutional markets. The lack of accessible local processing and distribution networks is viewed as particularly limiting to the capacity of small- and midsized farmers to participate in institutional markets. This lack of accessible distribution networks in turn limit the ability of these farmers to compete with larger farmers, who tend to have stronger ties to major processors, distributors, and brokers. Two peri-urban agents stated:

We just don't have the infrastructure to deliver product to the institutions.... The current national design of distribution, lack of regional infrastructure to support a local system. These are some of the issues that must be addressed in order to move us forward.

Another challenge identified by some agents is infrastructural deficiencies within some institutions. One example is a lack of food handling and preparation capacity in institutional food service facilities, particularly public schools and hospitals. One agent describes this:

It will take a bit of work to engage with schools.... The reality is that most schools are not equipped to handle fresh produce.... They do not have processing equipment....They take it [processed food] out of a cooler and pop it in the microwave....Some schools do not have full kitchens anymore.

\section{Lack of strong network ties between local} producers and institutional buyers impedes indirect market development. Many extension agents reported that only a few of their farmers are connected to or contract with local indirect markets. Agents describe these relationships as exclusive, entrenched in inert social exchanges, and based on low cost-values. A crucial limiting factor identified by agents is limited capacity of small- and midsized farmers to produce high volumes on a routine basis. Institutional buyers are less inclined to work with small- and midsized farmers due to this limited capacity to meet their demands. One urban agent described the problem: "It is tough to get into it...It is a game, based on relationships. Brokers will maintain relationships with farmers that are proven to supply what they need and when they need it."

Several agents indicated that the key to the expansion and success of local indirect exchanges is for farmers to develop strong relationships or ties with these businesses. According to agents, many small- and midsize farmers are not part of large and/or strong institutional networks, and therefore are considerably limited in accessing new markets. Agent-identified mechanisms for making more connections to new institutional markets included hosting local dinners and farm tours.

While some agents reported having marginal success with these strategies, others described difficulties in establishing and sustaining these ties. An urban county agent stated that trying to develop these connections is difficult in the private processing, distribution, and retail outlets. According to a peri-urban agent, establishing relationships with other indirect markets such as local restaurants is fairly easy; the challenge is maintaining these relationships: "[Building relationships is] actually easier than you think...The hard part is once you raise that awareness then somebody has got to make sure that all of these partners stay connected."

\section{Discussion}

The same types of local food markets are being promoted in each county of the study area despite variation in proximity to population centers and in socio-economic conditions (e.g., median income, minority population, and education attainment). The Cooperative Extension agents themselves identified this as a problem, indicating that what they promote is being driven by institutional training and state-level policy, rather than from any analysis of local conditions and market demand. This suggests that institutional factors (e.g., program orientation, training, rules and/or norms) may be exerting more influence on choice of market strategies than relevant basic socioeconomic and geographic characteristics.

In support of their view that local food market success is contingent upon local context, agents 
identified local conditions and factors that contribute to the potential success or failure of a food market (Tables 3 and 4). Among the most commonly mentioned factors impeding local food market development is farmer reluctance to change the way they operate. The agents noted that farmers' attitudes are substantially influenced by their perceived ability to meet demand, the relative novelty of the suggested strategy, their past experiences, and the existing local and macro food system conditions (e.g., community/regional food infrastructure and food policy). The agents believe that in order to progress farmers need to diminish their reluctance to change practices and strategies that have worked in the past, and that farmers are working against their best interests by not taking advantage of offered opportunities.

Agents' observations are consistent with past studies showing that farmers tend to be risk adverse (Binswanger \& Sillers, 1983; Feder, 1980). However, the view from the farmer's perspective offers a very different interpretation. Given the risks associated with change, their risk aversion can be viewed as economically rational and appropriate decision-making rather than as a failure of initiative. If experience tells them that taking risks, such as attaining GAP certification, will result in a net loss rather than a gain in profitability, then it is reasonable for them to choose not to take such risks. From an economic perspective, therefore, the resistant behaviors of farmers can be viewed as a reasonable risk mitigation mechanism adopted in response to uncertainty, high transaction costs (Hardesty, 2008), low access to capital resources, and high average age. These can be considered contingency factors affecting farmer decisions.

Another contingency factor influencing their decision-making is lack of suitable intermediary infrastructure, such as appropriately sized processing facilities, distribution, and brokering networks to facilitate exchanges between smalland midsized growers and indirect markets. Efforts are being made in North Carolina, as in many states, to address this infrastructure gap, but with only limited success. For example, one strategy being promoted in this region is the development of food hubs, a commonly promoted market strategy for connecting small- and midsized farms

\section{Table 4. Barriers to Indirect Market Development}

- Local indirect market arrangements are challenged by producer cost, uncertainty, and risk regarding labor and production; indirect market transactions are challenged by the producers' limited land and capital resource capacity

- Farmer attitudes towards change are viewed as significant barriers to their access to indirect markets

- Institutional and cultural barriers impede local indirect market arrangements between county farmers and local institutional food buyers

- Food system policy limits small-scale producer access

- Insufficient regional infrastructures create barriers to entry to indirect markets

- Lack of strong network ties between local producers and indirect market organizations

to larger and more profitable intermediated markets (Schmidt, Kolodinsky, DeSisto, \& Conte, 2011; Stevenson et al., 2011). However, the feasibility and profitability of this market strategy has not been demonstrated to farmers. This has contributed to a challenge described by agents in this study: difficulty encouraging development of strong ties between small- and midscale farmers and vendors of local indirect markets.

Recognizing these types of system-level contingencies is an important step that organizations and policy makers can take toward leveling the playing field for small-scale farmers with limited resources (Anderson, 2007). Once these challenges are recognized, assistance organizations and policy agencies must then generate the energy and resources necessary to mitigate contingency factors, a step that is critical for convincing small- and midscale farmers to adopt new practices and participate in new market opportunities. If farmers observe real efforts toward resolving issues aligned with their concerns, they may be more willing to take on more risks. For instance, increased availability of intermediary food infrastructure might convince farmers that the costs of participation, such as GAP certification and production expansion, are justified. Additional research is needed on how assistance agencies can facilitate the establishment, development, and sustainability of necessary infrastructure, whether social or physical, to establish and support strong network ties between small- and midscale farmers and intermediary organizations and services. This 
information can help planners, developers, and change agents build more sustainable and effective local food systems.

At present, most of the burden of changing LFSs is placed on the individual farmer. Strategies promoted by agricultural assistant agencies focus on actions individual farmers need to take in order to gain access to established local institutional food markets and to build consumer demand for direct market outlets. Small- and midscale farms on their own lack the resources to meet demands and adhere to standards imposed by the institutional food system. In addition, they lack access to concentrated populations of consumers willing to pay premium price for locally and/or sustainably grown products. Without these premium prices, small- and midscale farms are unable to sustain operations at a level that generates reasonable profit margins.

Given this business context, farmers are quite reasonably skeptical about getting involved in new ventures, and feel increasingly excluded from participation in the food system. This study suggests that there may be substantial disconnect between farmers' and assistance organizations' capacity and expectations in terms of working with one another. Relationships between farmers and assistance organizations such as Cooperative Extension are likely to erode if the assistance organizations continue to push strategies that farmers believe poorly fit their capacities and have a low likelihood of success.

If the local food movement is to succeed in enhancing the livelihoods of disadvantaged groups, such as small- and midscale farmers, then systemic changes must take place within the current food system to support their participation. More than one part of the system must be fixed in order for more profitable market arrangements to exist at the local level; farmers cannot do it all themselves. Small- and midsized farms cannot survive and prosper unless the agriculture system and policies are restructured in a way that fits their needs and capacities. Therefore, given the significance of institutional factors in creating challenges in local food market development, it is important to study how LFS design can accommodate local contexts such as institutional buying cultures and the policies local farmers must adhere to.

Considering the small sample size, the findings in this study may not be generalizable to all contexts. However, we believe that the richness of the information provides some knowledge that can be transferred to most contexts. For instance, we believe that in the development and implementation stages of food system change certain contingency factors (i.e., local context factors or conditions) should be considered (Table 5). We also believe that consideration of these factors promotes a more holistic view of local food system development, which will improve the sustainability and resilience of food systems as a whole.

\section{Table 5. Contextual Factors Stakeholders Should Consider When Developing Local Food Systems}

\begin{tabular}{ll}
\hline Type of Contingency Factor & Example of Contingency Factors \\
\hline Institutional Factors & - Institutional demand and buying cultures \\
& - Food production, handling, safety policy (e.g., GAP) \\
\hline Infrastructural Factors & - Existing aggregation, processing, and distribution networks \\
\hline Socioeconomic Factors & - Disadvantaged groups (e.g., small-scale farmers and low- \\
& income households), access to food markets \\
\hline Food Production Capacity & - Total farmland available \\
& - Number of existing farms \\
& - Farm labor/workforce \\
\hline Economic Factors & - Local demand \\
& - Food prices \\
& - Land taxes \\
\hline
\end{tabular}

\section{Conclusions}

The experiences of Cooperative Extension agents charged with implementing key aspects of North Carolina's local food system policies support the contingency perspective view, that the design of a local food system market structure should be driven by local context; local food market strategies that work in one place are not necessarily going to work 
in another. This may be particularly true when strategies developed for urban areas are transferred to rural settings. We suggest that two things must be kept in mind when attempting to develop more accommodating local food systems: (1) local food promotion will not be successful if the local context does not support it; (2) local conditions matter: there is no one-size-fits-all design for local food systems.

Development of a locally relevant strategy requires considerable effort. While not explicitly noted in the findings, many agents highlighted the fact that they lacked sufficient time and resources to commit to local food system development goals. Additional support is needed for agricultural and community assistance organizations such as Cooperative Extension to continue to support the goals of the local food movement. Support includes more refined tools and guidelines to help local agents assess local conditions (such as the ones outlined in Table 5) so that they can promote relevant strategies and reduce local barriers to market success. Further research is needed regarding what strategies are most suited for different types of farms. Perhaps most importantly, agencies need to allocate adequate time and resources for agents to successfully lead and facilitate system change. Agents cannot succeed if this responsibility is simply added on top of existing job responsibilities.

Policies at the federal and state levels need to better support the initiatives that assistance organizations are attempting to implement. They can do so by coordinating and synchronizing efforts so as to reduce conflicting and confusing requirements that impede progress at local levels.

Our findings support the view that the fit between local conditions, policy, and strategy impacts the performance of local food systems. If the goal of local food development is to create more equitable and sustainable food systems for all (Hendricks, 2000), then careful consideration must be given to local contextual features. Failure to consider local contingencies will limit certain groups and locales from realizing the potential benefits of local food systems, in effect diminishing the promise of more inclusive and equitable food systems.

\section{References}

Anderson, M. D. (2007). The case for local and regional food marketing. East Battle Creek, Michigan: W. K. Kellogg Foundation, Farm and Food Policy Project. Retrieved from http://www.farmlandinfo. org/case-local-and-regional-food-marketing

Andreatta, S., \& Wickliffe, W. (2002). Managing farmer and consumer expectations: A study of a North Carolina farmers market. Human Organization, 61(2), 167-176. http://dx.doi.org/10.17730/humo.61.2. $\underline{\mathrm{a} 4 \mathrm{~g} 01 \mathrm{~d} 6 \mathrm{q} 8 \mathrm{djj} 5 \mathrm{lkb}}$

Beratan, K., Jackson, P., \& Godette, S. (2014). Fostering capacity building among groups of disadvantaged farmers, southeastern North Carolina (USA). Journal of Agriculture, Food Systems, and Community

Development, 4(3), 61-78, http://dx.doi.org/10.5304/jafscd.2014.043.001

Beierlein, J., Schneeberger, K., \& Osborn, D. (2003). Principles of agribusiness management (3rd Ed.). Long Grove, Illinois: Waveland Press.

Binswanger, H. P., \& Sillers, D. A. (1983). Risk aversion and credit constraints in farmers' decision-making: A reinterpretation. Journal of Development Studies, 20(1), 5-21. http://dx.doi.org/10.1080/00220388308421885

Bloomberg, L. D., \& Volpe, M. (2012). Completing your qualitative dissertation: $A$ road map from beginning to end. Thousand Oaks, California: SAGE.

Byczynski, L. (2013). Market farming success: The business of growing and selling local food (2nd $\mathrm{Ed}$.). White River Junction, Vermont: Chelsea Green.

Center for Environmental Farming Systems, The [CEFS]. (n.d.). The NC 10\% Campaign. Retrieved 2012 from http://www.cefs.ncsu.edu/whatwedo/ foodsystems/10percent.html

Dahlberg, K. A. (1994). Alternative visions: Localizing food systems. The Neighborhood Works, 17(1), 14.

Dunning, R., Creamer, N., Lalekacs, J. M., O’Sullivan, J., Thraves, T., \& Wymore, T. (2012). Educator and institutional entrepreneur: Cooperative Extension and the building of localized food systems. Journal of Agriculture, Food Systems, and Community Development, 3(1), 99-112.

http://dx.doi.org/10.5304/jafscd.2012.031.010

Feder, G. (1980). Farm size, risk aversion, and the adoption of new technology under uncertainty. Oxford Economic Papers, 32(2), 263-283. 
Friedmann, H., \& McNair, A. (2008). Whose rules rule? Contested projects to certify 'local production for distant consumers.' Journal of Agrarian Change, 8(2-3), 408-434. http://dx.doi.org/10.1111/j.1471$\underline{0366.2008 .00175 . x}$

Ginsberg, A., \& Venkatraman, N. (1985). Contingency perspectives of organizational strategy: A critical review of the empirical research. Academy of Management Review, 10(3), 421-434.

Guba, E. G.,\& Lincoln, Y. S. (1998). Competing paradigms in qualitative research. In N. K. Denzin \& Y. S. Lincoln (Eds.), Handbook of qualitative research (pp. 105-117). Thousand Oaks, California: SAGE.

Hardesty, S. D. (2008). The growing role of local food markets. American Journal of Agricultural Economics, 90(5), 1289-1295. http://dx.doi.org/10.1111/ j.1467-8276.2008.01219.x

Heiens, R. A., \& Pleshko, L. P. (2011). A contingency theory approach to market orientation and related marketing strategy concepts: Does fit relate to profit performance? Management \& Marketing, 6(1), 19-34.

Hinrichs, C.C. (2000). Embeddedness and local food systems: Notes on two types of direct agricultural market. Journal of Rural Studies, 16(3), 295-303. http://dx.doi.org/10.1016/S0743-0167(99)00063-7

Ilbery, B., Watts, D., Simpson, S., Gilg, A., \& Little, J. (2006). Mapping local foods: Evidence from two English regions. British Food Journal, 108(3), 213225. http://dx.doi.org/10.1108/00070700610651034

Jones, P., \& Bhatia, R. (2011). Supporting equitable food systems through food assistance at farmers' markets. American Journal of Public Health, 101(5),781-783.

http://dx.doi.org/10.2105/AJPH.2010.300021

Local Harvest. (2011). National directory. Retrieved August 2011 from http://www.localharvest.org/

Low, S. A., \& Vogel, S. (2011). Direct and intermediated marketing of local foods in the United States (Report No. ERR-128). Washington, D.C.: USDA, Economic Research Service. Retrieved from http://www.ers.usda.gov/publications/erreconomic-research-report/err128.aspx

Maples, M., Morgan, K. L., Interis, M. G., \& Harri, A. (2013). Who buys food directly from producers in the southeastern United States? Journal of Agricultural and Applied Economics, 45(3), 509-518.
Martinez, S., Hand, M., DaPra, M., Pollack, S., Ralston, K., Smith, T., Vogel, S. Clark, S., Lohr, L., Low, S., \& Newman, C. (2010). Local food systems: Concepts, impacts, and issues (Report No. ERR-97).

Washington, D.C.: USDA, Economic Research Service. Retrieved from http://www.ers.usda.gov/ publications/err-economic-research-report/ err97.aspx

McKenzie, D., \& Smith, W. (1999). Fostering sustainable behavior: An introduction to community-based social marketing (2 ${ }^{\text {nd }}$ Ed.). Gabriola Island, B.C.: New Society.

Mettam, L., King, B., \& Dunning, R. (2013). A community and local government guide to developing local food systems in North Carolina (AG-744). Raleigh, North Carolina: The Center for Environmental Farming Systems. Retrieved from http://www.cefs.ncsu.edu/ publications/guide-to-developing-local-foodsystems-in-nc.pdf

Mirosa, M., \& Lawson, R. (2012). Revealing the lifestyles of local food consumers. British Food Journal, 114(6), $816-825$. http://dx.doi.org/10.1108/00070701211234345

North Carolina Department of Agriculture and Consumer Services. (2012). North Carolina state level data. Raleigh, North Carolina: NCDA \& CS Agricultural Statistics Division. Retrieved August 2012 from http://www.ncagr.gov/stats/census/census.htm

Office of Management and Budget. (2011). Metropolitan and micropolitan statistical areas main page. Washington, D.C.: U. S. Census Bureau. Retrieved August 2011 from http://www.census.gov/population/metro/

O'Hara, S. U., \& Stagl, S. (2001). Global food markets and their local alternatives: A socio-ecological economic perspective. Population and Environment, 22(6), 533-554. http://dx.doi.org/10.1023/A:1010795305097 Schmidt, M. C., Kolodinsky, J. M., DeSisto, T. P., \& Conte, F. C. (2011). Increasing farm income and local food access: A case study of a collaborative aggregation, marketing, and distribution strategy that links farmers to markets. Journal of Agriculture, Food Systems, and Community Development, 1(4), 157175. http://dx.doi.org/10.5304/jafscd.2011.014.017 
Shenhar, A. J. (2001). One size does not fit all projects: Exploring classical contingency domains. Management Science, 47(3), 394-414. http://dx.doi.org/10.1287/mnsc.47.3.394.9772

Smith, C. S.,\& Miller, H. (2011). Assessing the food systems in urban and rural Minnesotan communities. Journal of Nutrition Education and Behavior, 43(6), 492-504. http://dx.doi.org/10.1016/j.jneb.2011.05.006

Stevenson, G. W., Clancy, K., King, R., Lev, L., Ostrom, M., \& Smith, S. (2011). Midscale food value chains: An introduction. Journal of Agriculture, Food Systems, and Community Development, 1(4), 27-34. http://dx.doi.org/10.5304/jafscd.2011.014.007

Tushman, M. L. (1977). Special boundary roles in the innovation process. Administrative Science Quarterly, 22(4), 587-606.

http://dx.doi.org/10.2307/2392402
Tushman, M. L., \& Scanlan, T. J. (1981). Boundaryspanning individuals: Their role in information transfer and their antecedents. Academy of Management Journal, 24(2), 289-305. http://dx.doi.org/10.2307/255842

U.S. Census Bureau. (2011). State \& county quickfacts: North Carolina. Washington, D.C.: U.S. Census Bureau. Retrieved from http://quickfacts.census. gov/qfd/states/37000.html

U.S. Department of Agriculture. (2012). Census of agriculture, 2012: North Carolina profiles. Washington, D.C.: USDA, Census of Agriculture. Retrieved from http://www.agcensus.usda.gov/ Census_by_State/North_Carolina/

U.S. Department of Agriculture, National Agricultural Statistics Service. (2012). North Carolina's rank in US agriculture, 2012. Washington, D.C.: USDA, NASS. Retrieved from http://www.nass.usda.gov 